\title{
Sustainable Approach for Recycling Medical Waste Needles to Partially Replace Aggregate in Lightweight Concrete Production
}

\author{
Lubna K. Hamada', Zainab Z. Ismail ${ }^{1 *}$ \\ 1 Department of Environmental Engineering, University of Baghdad, Baghdad, Iraq \\ * Corresponding author's emails: zismail9@gmail.com; zismail3@gatech.edu
}

\begin{abstract}
The generation of sharp waste from the activities of health care facilities is unavoidable. Waste needles are considered one of the most problematic issues in health facilities. This study involved an experimental investigation of reusing waste needles (WNs) in concrete mixes to partially replace the natural fine aggregate at $0 \%, 2 \%, 4 \%$, $6 \%, 8 \%$ and $10 \%$ by weight. The mechanical and physical properties of the WNs-concrete mixes have been studied and compared to conventional concrete mix. The workability test, fresh and hard densities, compressive and flexural strengths, water absorption, and leaching test were carried. The curing ages considered for the concrete mixes were 7, 14, and 28 days. The results revealed that the WNs-concrete mixes exhibited improved flexural strength and workability, decreased water absorption capacity and improved durability. The compressive strength values of WNs-concrete mixes gradually decreased, but they were higher than the targeted mean strength of M17 grade concrete.
\end{abstract}

Keywords: concrete; biomedical waste; reuse; waste needles, sustainability

\section{INTRODUCTION}

Hospital waste is a special category of waste. Due to its infectious and / or toxic properties, it has become a growing environmental concern in developing countries in terms of managing, treating and disposing of these wastes [1]. Medical waste management is a major problem and a basic public health concern. Proper management of medical waste needs planning for proper collection, safe storage, systematic transportation and disposal. Hospital waste considered hazardous because it can transmit infection to people [2]. Large quantities of medical waste are generated, but they cannot be disposed of completely. However, their environmental impact can be reduced through the sustainable reuse of these wastes, and this is known as the hierarchy. Waste, as it is intended for reuse, reduction, and recycling [3]. Wise use of resources is achieved through the use of by-products and recyclables, as well as less environmental impact is achieved by reducing aggregate mining from quarries and reducing carbon dioxide emissions; these are the two main measures that pave the way for the sustainable development of construction activities [4].

On the other hand, in the construction and development of infrastructure, concrete is one of the primary materials. Waste can be utilized in concrete either as a substitute for aggregates or cement, fibers or fillers. Waste can be used to replace the aggregate in construction, as it is difficult to use as a substitute for cement. Seventy percent of concrete volume is aggregate, and given that large quantities of waste can be reused, this is a critical choice for countries with a shortage of minerals to avoid consumption of raw materials that are rare in some countries. Tremendous studies were previously reported regarding the use of various waste materials in concrete mixes. These waste materials include, but not limited to waste iron filings [5], waste plastic [6-10], waste glass [11-13]. However, very limited studies have been reported concerning the use of hazardous medical 
waste materials in concrete mixes. Al-Akhras et al. [14] investigated the stabilization of medical waste ash (MWA) in concrete mixes through partial replacement of aggregate by $5 \%, 10 \%$ and $15 \%$. The slump, setting time, flexural and compressive as well as leaching of heavy metals were explored. The results indicated that MWA can be stabilized in concrete mixes without considerable leaching of heavy metals. Malavan and Manju [15] examined the partial replacement of sand in concrete mixes by biomedical waste (BMW) ash. The results demonstrated that density of concrete mixes prepared with BMW ash decreased with increasing the replacement percentage. The compressive strength, split tensile and flexural strength values of BMW-modified concrete were less than those for the plain concrete. Kumar and Pandey [16] examined the utilization of the discarded waste hospital plastic as aggregate in concrete mixes and its influence on the slump and compressive strength of the concrete. Tailor and Shastri [17] studied the feasibility and effect of using biomedical waste (BMW) ash to partially replace cement in concrete mix. Akyildiz et al. [18] explored the results of stabilization /solidification of biomedical waste ash (BMWA) into cement matrix. The results revealed that compressive strength decreased with increasing the BMWA ratio. The stabilization / solidification prohibited leaching of heavy metals from BMWA. Ababneh et al. [19] studied the pretreatment of medical waste fly ash (MWFA) to remove heavy metals and then the possibility of reusing the pretreated MWFA in concrete mixes. Sathvik et al. [20] examined the validity of biomedical waste (BMW) ash usage to partially replace cement in concrete mixes. The results demonstrated that workability of BMW-modified concrete mix was lower than that for the plain concrete mix. Whereby, the compressive strength and the split tensile for BMW-modified concrete decreased with increasing the replacement ratio with an optimum of $10 \%$ replacement. Prasanth and Rao [2] studied the split tensile strength, compressive strength, and durability of concrete mixes prepared biomedical waste ash to partially replace cement with different percentages of 5\%, $10 \%, 15 \%$ and $20 \%$ as well as keeping Meta kaolin $20 \%$ constant. Binu et al. [21] examined the mechanical properties of paver blocks prepared with partial replacement of coarse aggregate. In addition to obtain paver blocks of reduced unit weight and cost, the environmental contamination arising from the disposing of waste hospital plastic will be reduced. The mechanical properties were examined. Kaur et al. [22] studied the influence of introducing incinerated biomedical waste (IBMW) ash in concrete mixes on the strength and penetration properties of concrete. Four different percentages of $5 \%, 10 \%, 15 \%$, and $20 \%$ were used to partially replace the sand by IBMW in concrete mixes.

To the authors knowledge, none of the previously reported studies considered the reuse or recycle the waste medical needles as a partial displacement of aggregate in concrete mixes. This study aimed to experimentally investigate the validity of reusing waste needles (WNs) in concrete mixes to partially substitute the fine aggregate as a new sustainable approach to reduce the environment impact of hazardous WNs. The characteristics of the newly prepared WNs- concrete mixes were examined by a number of fundamental tests for concrete, including compressive and flexural strengths, fresh and dry densities, workability, water absorption, and leaching.

\section{MATERIALS AND METHODS}

\section{Materials}

All the materials utilized in this study were provided by the Iraqi local markets. Type 1 ordinary Portland cement (OPC) which is commercially known as (Taslooja) was utilized in all concrete mixes. The chemical analysis and physical properties of OPC are given in Tables (1) and (2), respectively.

The coarse aggregate was crushed gravel of maximum size (20) $\mathrm{mm}$ acquired from Tikrit city. Physical properties and sieve analysis of the coarse aggregate are shown in Tables (3) and (4), respectively. The fine aggregate was river sand obtained from the Al-Zawiya zone north of Tikrit city with maximum aggregate size of $5 \mathrm{~mm}$. Physical properties and sieve analysis are given in Tables (5) and (6), respectively.

Waste needles (WNs) were used as the waste medical material. They were collected from the local hospitals, health centers, and medical clinics. After collection, the waste needles were autoclaved, and then manually cut into small pieces, each of length in the range $0.5-1.5 \mathrm{~cm}$. The volumetric mass density of the needles pieces was $1455 \mathrm{~kg} / \mathrm{m}^{3}$. The needles used in this study are 
Table 1 Chemical composition of cement

\begin{tabular}{|l|c|c|}
\hline \multicolumn{1}{|c|}{ Compounds } & Abbreviation & Weight (\%) \\
\hline Lime & $\mathrm{CaO}$ & 61.65 \\
\hline Silica & $\mathrm{SiO}_{2}$ & 21.25 \\
\hline Alumina & $\mathrm{Al}_{2} \mathrm{O}_{2}$ & 4.40 \\
\hline Iron oxide & $\mathrm{Fe}_{2} \mathrm{O}_{3}$ & 3.30 \\
\hline Sulfite & $\mathrm{SO}_{3}$ & 2.10 \\
\hline Magnesia & $\mathrm{MgO}$ & 1.89 \\
\hline Loss of ignition & $\mathrm{L.O.I}$ & 1.58 \\
\hline $\begin{array}{l}\text { Lime saturation } \\
\text { factor }\end{array}$ & $\mathrm{L.S.F}$ & 0.89 \\
\hline Insoluble residue & $\mathrm{I.R}$ & 0.49 \\
\hline Tricalcium silicate & $\mathrm{C}_{3} \mathrm{~S}$ & 48.13 \\
\hline Dicalcium silicate & $\mathrm{C}_{2} \mathrm{~S}$ & 26.43 \\
\hline $\begin{array}{l}\text { Tricalcium } \\
\text { aluminate }\end{array}$ & $\mathrm{C}_{3} \mathrm{~A}$ & 6.30 \\
\hline $\begin{array}{l}\text { Tetra calcium } \\
\text { aluminoferrite }\end{array}$ & $\mathrm{C}_{4} \mathrm{AF}$ & 8.96 \\
\hline
\end{tabular}

of different gauges. Fig. 1 presents samples of the waste medical needles (WNs).

\section{Proportioning of concrete mixes}

Two types of concrete mixes were designed in this experimental study. The first mix was the plain concrete, which consisted of $715 \mathrm{~kg} / \mathrm{m}^{3}$ fine aggregate, $1020 \mathrm{~kg} / \mathrm{m}^{3}$ coarse aggregate, $380 \mathrm{~kg} / \mathrm{m}^{3}$ cement and $174.8 \mathrm{~kg} / \mathrm{m}^{3}$ water with $\mathrm{W} / \mathrm{C}$ ratio of 0.46 . The second type of mixes was is the concrete with waste needles as partial replacement of fine aggregate (sand) by $2 \%, 4 \%$, $6 \%, 8 \%$ and $10 \%$ weight percent. Both, the plain concrete and WNs-concrete mixes were cured for 7,14 , and 28 days.

\section{Specimens and test of specimens}

Fifty-four concrete cubes, each of size $(150 \times 150 \times 150) \mathrm{mm}$ were prepared and shaped for compressive strength test. For fresh and hard densities, and water absorption tests, one hundred and sixty-two concrete cubes, each of size

Table 3 Physical properties of gravel

\begin{tabular}{|l|c|c|}
\hline \multicolumn{1}{|c|}{ Properties } & Values & $\begin{array}{c}\text { Limit of I.Q.S No. } \\
45 / 1984[24]\end{array}$ \\
\hline Specific gravity & 2.52 & - \\
\hline Bulk density $\left(\mathrm{kg} / \mathrm{m}^{3}\right)$ & 1500 & - \\
\hline Absorption (\%) & 0.50 & - \\
\hline $\begin{array}{l}\text { Sulfate content (as } \\
\text { SO3) }(\%)\end{array}$ & 0.014 & 0.5 (Max.) \\
\hline
\end{tabular}

Table 2 Physical properties of cement

\begin{tabular}{|l|c|c|c|}
\hline \multicolumn{1}{|c|}{ Compounds } & Abbreviation & $\begin{array}{c}\text { Limits of } \\
\text { cement }\end{array}$ & $\begin{array}{c}\text { *Limit of I.Q.S } \\
\text { No. 5/1984 } \\
\text { [23] }\end{array}$ \\
\hline Finesse $\left(\mathrm{m}^{2} / \mathrm{kg}\right)$ & - & 300 & $\geq 230$ \\
\hline $\begin{array}{l}\text { Initial setting } \\
\text { time (min) }\end{array}$ & I.S.T & 131 & $\geq 45 \mathrm{~min}$ \\
\hline $\begin{array}{l}\text { Final setting } \\
\text { time (h) }\end{array}$ & F.S.T & 240 & $\leq 10 \mathrm{~h}$ \\
\hline $\begin{array}{l}\text { Soundness (\%) } \\
3 \text { days age } \\
\text { compressive } \\
\text { strength (MPa) }\end{array}$ & - & - & $\leq 0.8$ \\
\hline $\begin{array}{l}7 \text { days age } \\
\text { compressive } \\
\text { strength (MPa) }\end{array}$ & $\mathrm{C}_{\mathrm{s}}$ & 35 & $\geq 15$ \\
\hline
\end{tabular}

* Iraqi standards based on ASTM

$(100 \times 100 \times 100) \mathrm{mm}$ were prepared. Seventy-two prisms, each of size $(70 \times 70 \times 380) \mathrm{mm}$ were prepared for flexural strength test. Nine cylinders of size $(50 \times 100) \mathrm{mm}$ were prepared for leaching test.

For the test of specimens, slump test was fulfilled according to ASTM C143-05 [25]. Casting, compacting and curing was conducted according to B.S.188:1952 [26]. Fresh density was conducted according to B.S:188:1952 [26], part 5 for the all-concrete mixes, immediately after molding and compacting the specimens. Dry density was measured according to B.S.1881:1952 [26], part 5. Three cubes represented the mean of the dry density.

Water absorption test was carried out according to ASTM C 642 - 97 [27]. The cubes of size $(100 \times 100 \times 100)$ were dried in an oven at a temperature of 100 to $110^{\circ} \mathrm{C}$ for $72 \mathrm{~h}$. The compressive strength test was conducted according to B.S:1881:1952 [27], part7. The specimens were tested after being taken out from the curing water in their wet condition in the compression machine which is a digital electrical compressing machine with a capacity of $2000 \mathrm{kN}$ was used with loading rate of $0.45 \mathrm{MPa} / \mathrm{sec}$. Flexural strength test was conformed to ASTM C293-07 [28]. This test involved applying a center point load on the

Table 4 Sieve analysis for gravel

\begin{tabular}{|c|c|c|}
\hline $\begin{array}{c}\text { Properties sieve } \\
\text { size }(\mathrm{mm})\end{array}$ & Passing \% & $\begin{array}{c}\text { Limit of I.Q.S } \\
\text { No. 45/1984 } \\
\text { zone (2) [24] }\end{array}$ \\
\hline 20 & 100 & $95-100$ \\
14 & 70.5 & - \\
10 & 46.1 & $30-60$ \\
5 & 1.9 & $0-10$ \\
pan & - & - \\
\hline
\end{tabular}


Table 5 Physical properties of sand

\begin{tabular}{|l|c|c|}
\hline \multicolumn{1}{|c|}{ Properties } & Values & $\begin{array}{c}\text { Limit of I.Q.S } \\
\text { No. 45/1984 [24] }\end{array}$ \\
\hline Specific gravity & 2.56 & - \\
\hline Bulk density $\left(\mathrm{Kg} / \mathrm{m}^{3}\right)$ & 1660 & - \\
\hline Absorption (\%) & 1.2 & - \\
\hline $\begin{array}{l}\text { Sulfate content (as } \\
\left.\mathrm{SO}_{3}\right)(\%)\end{array}$ & 0.13 & 0.5 (Max.) \\
\hline
\end{tabular}

specimen until failure occur. Four prisms represented the mean of the flexural strength.

\section{Leaching test}

The chemical characterization for metal leaching from WNs- concrete mixes was carried out after 28 and 90 days of curing according to EPA SW-846 [29]. Test specimens were hanged and submerged in container filled with 2 liters of the leaching fluid which was double distilled water. The cylinders were divided into 2 groups, one group was the reference group, and the second group has $10 \%$ replacement of sand for needles. Target trace elements were Iron (Fe) and Nickel (Ni) as well as total dissolved solids (TDS) were conducted for the leachant. Iron (Fe) and Nickel (Ni) were detected by Atomic Absorption Spectrum (Model: GBC A.C.N. 005472 686, Australia), whereby TDS was measured according to the procedure outlined in the Standard Methods [30]. A side test was carried out using unautoclaved WNs in concrete mix to examine the effect of pathogens or infectious species if existed in case of using the contaminated WNs.
Table 6 Sieve analysis for sand

\begin{tabular}{|c|c|c|}
\hline Sieve size $(\mathrm{mm})$ & Passing \% & $\begin{array}{c}\text { Limit of I.Q.S } \\
\text { (No. 45/1984) [24] }\end{array}$ \\
\hline 10 & 100 & 100 \\
4.75 & 91.5 & $90-100$ \\
2.36 & 80.0 & $75-100$ \\
1.18 & 56.5 & $55-90$ \\
0.60 & 42.1 & $35-59$ \\
0.30 & 10.9 & $8-30$ \\
0.15 & 3.6 & $0-10$ \\
\hline
\end{tabular}

\section{RESULT AND DISCUSSION}

\section{Slump test}

The effect of partial replacement of WNs on the slump test is presented in Fig. 2. The results showed the trend of slump to decrease beneath the plain mix by $1.6 \%, 3.2 \%, 5.1 \%, 6.9 \%$ and $10.2 \%$ for waste needles ratio of $2 \%, 4 \%, 6 \%, 8 \%$, and $10 \%$. This tendency might be due to the smooth surface of the needles, which restrict the movement of the water in concrete, this restriction caused lower fluidity of the mixes. A similar observation was reported by Ismail and Al-Hashime [5] for using waste iron filings to partially substitute sand in concrete mix. They suggested that the slump of the fresh concrete decreased with the increasing the percentage of waste iron filing. This decrease might be due to the shape of the iron filing particles.

\section{Tests of fresh and dry densities}

Results of fresh density test of the WNs-concrete mixes are shown in Fig.4. The fresh density
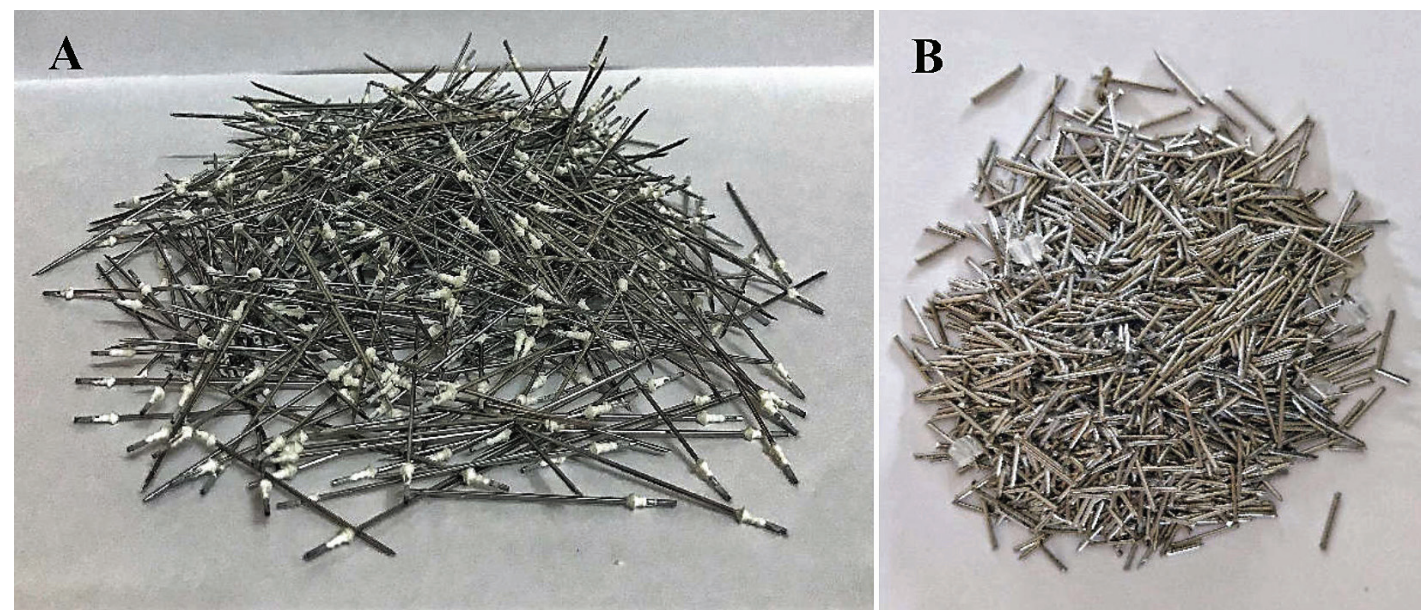

Fig. 1. Sample of needles; (A) before cut, (B) after cut into small pieces 


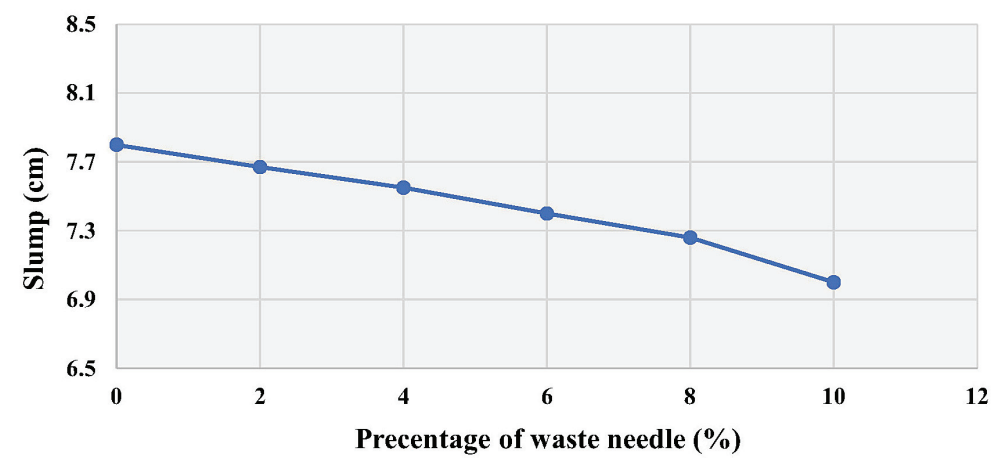

Fig. 2. Profile of slump test for concrete mixes

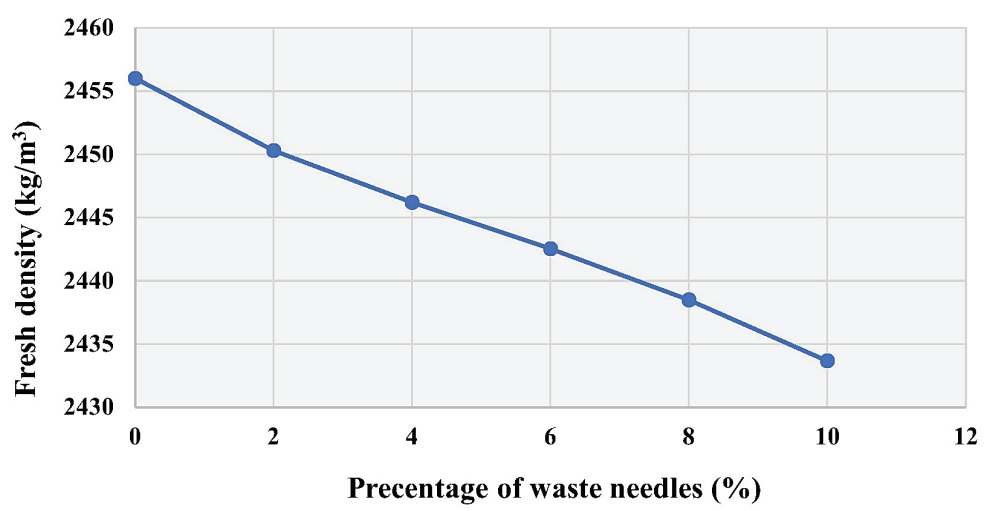

Fig. 3. Profile of fresh density for concrete mixes

tends to decrease slightly with increasing of the replacement ratio. The decrease in the density values of the WNs- concrete mixes were $0.23 \%$, $0.39 \%, 0.54 \%, 0.71$ and $0.91 \%$ for mixes with $2 \%, 4 \%, 6 \%, 8 \%$ and $10 \%$, respectively of waste needles replacement ratio. The decrease in the density may be due to the density of the needles, which is lower than the sand by $12.35 \%$. The dry density tests for the WNs- concrete mixes are shown in Fig.4. The dry densities of the WNs-concrete mixes decreased with increasing the ratio of the waste needles at each curing age. The lowest dry density was $2366 \mathrm{~kg} / \mathrm{m}^{3}$ at 28 days curing age. The use of WMN for each curing age reduced the dry density slightly with the increasing of the waste ratio most likely due to the fact that the density of the cut needles pieces was lower than the sand density by $12.35 \%$.

\section{Water absorption}

The weight percentage of absorbed water in concrete mixes are illustrated in Fig.5. The results demonstrated that the water absorption tendency, decreased with increasing the ratio of WNs. This decrease in water absorption may be due to the needles shape, which may fill the voids between the cement and aggregate. The decrease of water

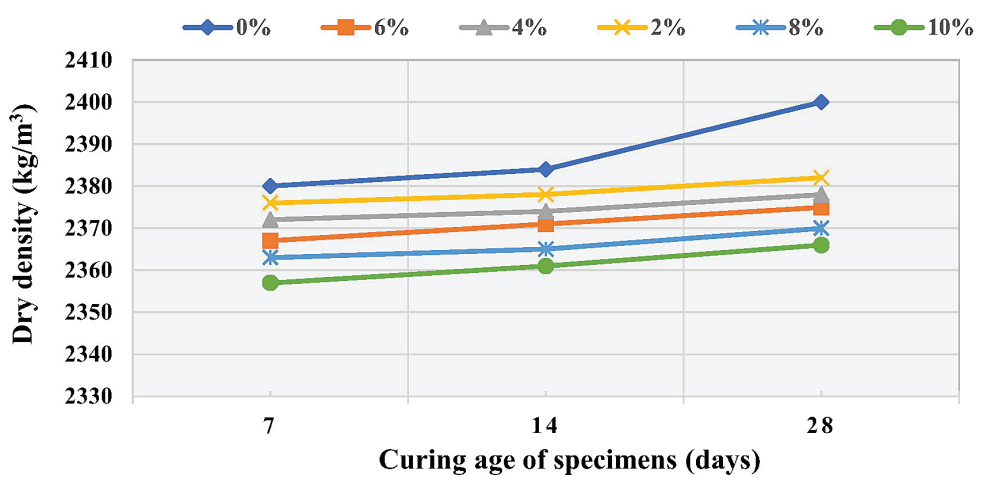

Fig. 4. Profiles of dry density of concrete mixes 


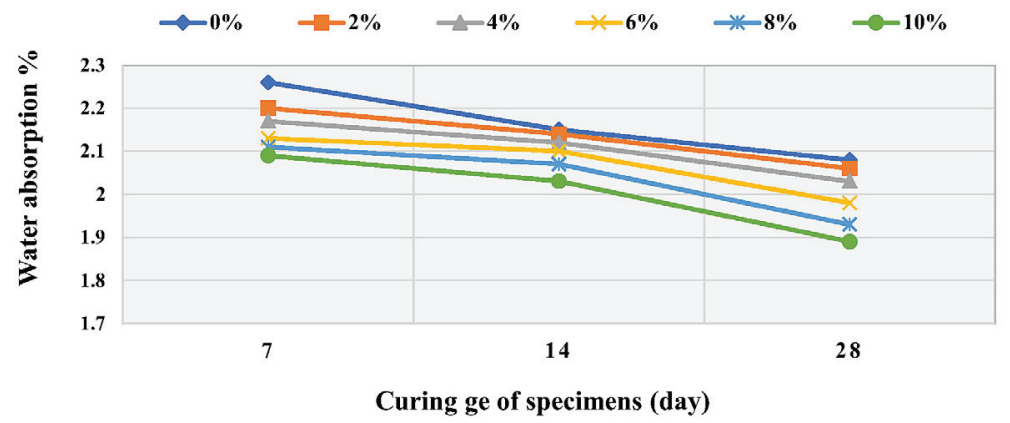

Fig. 5. Water absorption of needle- concrete

absorption with time referred to a modification of total void space in concrete. In a related study, Miah et al. [31] observed a similar trend using waste iron as fine aggregate. They reported that the water absorption decreased with the increasing the ratio of iron waste. Ismail and Jaeel [32] stated that long-term performance could be enhanced by the reduction of the porosity and water absorption.

\section{Compressive strength tests}

Results of compressive strength for concrete mixes at 7, 14, and 28 days are shown in Fig.6. The results of compressive strength test revealed that the compressive strength of WNs-concrete increased slightly with increasing the ratio of WNs small pieces, but still lower than that for the plain concrete mix at 14- and 28-days curing days. However, the minimum value of compressive strength was (34 MPa) for $2 \%$ replacement of aggregates at 7 days of curing age which was higher than the minimum value (17.4MPa) of lightweight concrete for structural application. This behavior could be attributed to the lower density of the needles compared to sand density, their strength, and their smooth texture. The best compressive strength was $44.4 \mathrm{MPa}$ at 28 curing age when the concrete specimens prepared with fine aggregate replacement of up to $10 \%$ WNs ratio.

\section{Test of flexural strength}

Results of flexural strength test for the WNs-concrete mixes are presented in Figure 7. The results show that the flexural strength of WNs-concrete mixes increased with increasing the ratio of WNs in these mixes. At 28-day curing, flexural strength for all mixes, became higher than the plain concrete mix. Noori and Ibrahim [33] reported that when iron waste was used as a fine aggregate, the flexural tensile strength gradually increased with the waste iron percentage until $12 \%$.

\section{Leaching test}

The results of leaching tests for the WNs-concrete mixes revealed the absence of the target constituents in the leachant as none of these constituents or any others were detected in the leachant. Also, the results of the leaching test for the unautoclaved WNs-concrete mixes demonstrated that no pathogens were detected in the leachant. The absence of any pathogens or kind like species could be due to their annihilation if they were existing along the duration until the

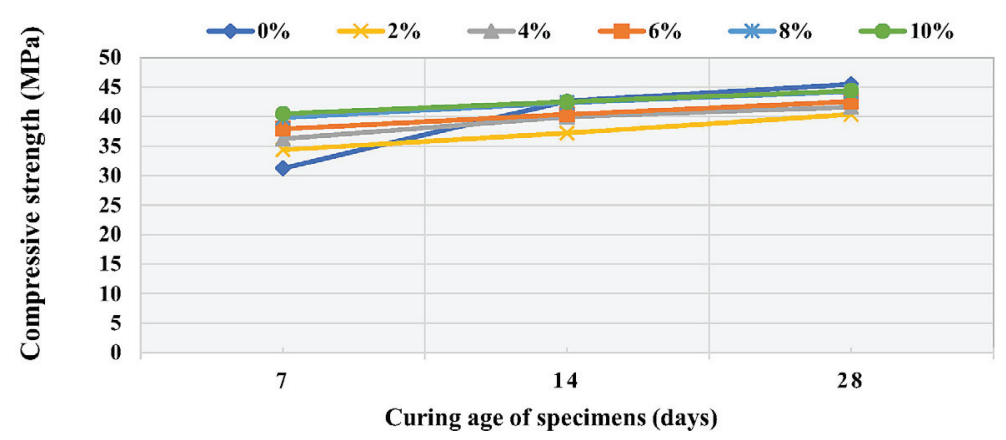

Fig. 6. Compressive strength of needle- concrete 


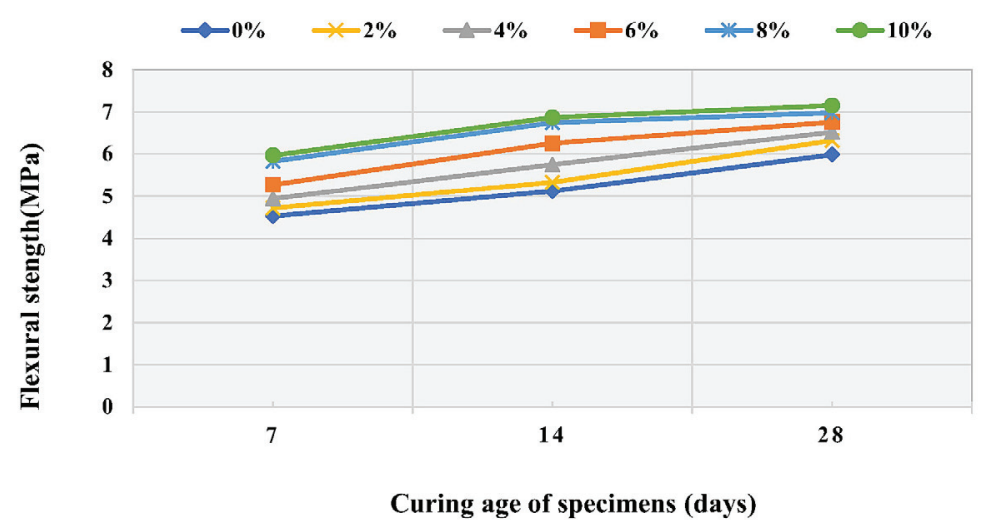

Fig. 7. Flexural strength of needle-concrete

test time. Also, their absence could be due to the unfavorable environment in the concrete matrix because of its high alkalinity, approximately 12 to 13 mostly due to calcium hydroxide, which is normally a by-product of cement hydration. These observations indicated that utilizing WNs in concrete mixes is non-hazardous and could meet the requirements of clean construction products.

\section{CONCLUSIONS}

This study aimed to investigate and evaluate the recycling of waste medical needles to partially replace the fine aggregate in concrete mixes. From environmental perspective, the results demonstrated an environmentally friendly sustainable approach for proper management of this hazardous medical waste. The results of slump tests of WNs -concrete mixtures decrease with increasing the waste content. Although the slump values of these mixes declined, those mixes were still workable. The fresh and dry density values decreased with increasing the WNs ratio in concrete mixes. Water absorption levels in the WNs- concrete mixes decreased with increasing the content of the WNs for all curing ages. Compressive strength of the concrete mixes slightly increased with increasing the WNs ratio. However, the minimum value of compressive strength was (34MPa) for $2 \%$ replacement of aggregates at 7 days of curing age but it was higher than the minimum value (17.4MPa) of lightweight concrete for structural application. Flexural strength values increased with increasing the ratio of WNs at all curing ages.

\section{Acknowledgement}

The authors would like to thank the Department of Civil Engineering, Tikrit University for their technical support.

\section{REFERENCES}

1. Ali M., Wang W., Chaudhry N., Geng Y. Hospital waste management in developing countries: A mini review. Waste Management Research. 2017; 35:581-592.

2. Prasanth B., Rao V.R. Flexural strength and durability of concrete by partial replacement of OPC with biomedical waste ash and metakaolin. International Journal of Recent Technology and Engineering. 2019; 7:352-358.

3. Batayneh M., Marie I., Asi I. Use of selected waste materials in concrete mixes. Waste Management. 2007; 27:1870-1876.

4. Moriconi G., Recyclable materials in concrete technology: sustainability and durability. Sustainable Construction Materials and Technologies, Special Sessions of First Inter. Conf. on Sustainable Construction Materials and Technologies, Coventry, UK, 2007; 11-13.

5. Ismail Z.Z., Al-Hashmi E.A. Reuse of waste iron as a partial replacement of sand in concrete. Waste Management. 2008a; 28: 2048-2053.

6. Krishna CH.B.R., Jagadeesh P. Strength and durability assessment of binary blended self-compacting concrete replacing partial sand with electronic plastic waste. International Journal of Innovative Technology and Exploring Engineering (IJITEE). 2019; 8:107-111.

7. Saikia N., Brito J.D. Use of plastic waste as aggregate in cement mortar and concrete preparation, a review. Construction and Building Materials. 2012; 34:385-401. 
8. Ismail Z.Z., Al-Hashmi E.A. Use of waste plastic in concrete mixture as aggregate replacement. Waste Management. 2008b; 28: 2041-2047.

9. Yazoghli-marzouk O., Dheilly R.M., Queneudec M. Valorization of postconsumer waste plastic in cementitious concrete composite. Waste Management. 2007; 27:1870-1876.

10. Rebeiz K.S. Time-temperature properties of polymer concrete using recycled PET. Cement and Concrete Composite. 2007;17: 603-608.

11. Ismail Z.Z., Al-Hashmi E.A. Recycling of waste glass as a partial replacement for fine aggregate in concrete. Waste Management. 2009; 29: 655-659.

12. Almesfer N., Ingham J. Effect of waste glass on the properties of concrete. Journal of Materials in Civil Engineering. 2014; 26: 06014022.

13. Sadiqul Islam G.M., Rahman M.H., Kazi M. Waste glass powder as partial replacement of cement for sustainable concrete practice. International Journal of Sustainable Built Environment. 2017; 6: 37-44.

14. Al-Akhras N.M., Al-Ghazawi Z.D., Al-Harafshah Z.D. Stabilization of medical waste ash in mortar mixtures. Waste Resources Management. Proceedings of the Institution of Civil Engineers. 2011; 164:117-124.

15. Malavan K., Manju R. An experimental investigation on bio-medical waste concrete. SSRG International Journal of Civil Engineering. 2017; 8: 854-857.

16. Kumar A., Pandey M. Reuse of hospital plastic waste in concrete as a partial replacement of coarse aggregate: A research paper. International Journal Management, IT \& Engineering. 2017;7: 68-75.

17. Tailor J.V., Shastri P.M. Review on concrete from biomedical waste. International Journal of Advanced Engineering Research and Development. 2017; 2: 36-40.

18. Akyildiz A., Kőse E.T., Yildiz A. Compressive strength and heavy metals leaching of concrete containing medical waste incineration ash. Construction and Building Materials. 2017; 138: 326-332.

19. Ababneh A., Al-Rousan R., Gharaibeh W., Abu-Dalo M. Recycling of pre-treated medical waste fly ash in mortar mixtures. Journal of Material Cycles and Waste Management. 2019. https:// doi.org/10.1007/s10163-019-00928-z.

20. Sathvik S., Suchith S., Edwin A., Jemimahcarmicheal M., Sheela V. Partial replacement of biomedical waste ASH in concrete. International Journal of Innovative Technology and Exploring Engineering (IJITEE). 2019; 8: 854-857.

21. Binu A.M., Vinod A.S., Sethuraj P., Akil S. Experimental study on the replacement of coarse aggregates with recycled hospital plastic waste in paver blocks. International Journal of Advanced Research and Development. 2019; 4:1-3.

22. Kaur H., Siddique R., Rajor A. Influence of incinerated biomedical waste ash on the properties of concrete. Construction and Building Materials. 2019; 226: 428-441.

23. Iraqi Specification No. 5/1984, Portland cement.

24. Iraqi Specification No. 45/1984, Natural sources for aggregate used in concrete and construction.

25. American Society for Testing and Materials. Standard test method for slump of hydraulic-cement concrete. ASTM C143/C143M-00, Annual book of ASTM standards. 2000.

26. British Standards Institution, Methods of testing concrete.B.S.1881, BSI, London. 1952.

27. American Society for Testing and Materials. Standard test method for density, absorption, and voids in hardened concrete. ASTM C642, Annual book of ASTM standards.1997.

28. American Society for Testing and Materials. Standard test method for flexural strength of concrete (using simple beam with center-point loading). ASTM C293, Annual book of ASTM standards. 1979.

29. USEPA. Mass transfer rates of constituents in monolithic or compacted granular materials using a semi-dynamic tank leaching procedure. Test methods for evaluating solid waste, physical/chemical methods SW-846 Method 1315. 2013.

30. American Public Health Association (APHA), 2005. Standard methods of the examination of water and wastewater, Washington, DC.

31. Miah M.J., Ali M. K., Paul S.C., Babafemi A.J., Kong S.Y., Šavija B. Effect of recycled iron powder as fine aggregate on the mechanical, durability, and high temperature behavior of mortars. Materials. 2020; 13:1168.

32. Ismail Z.Z., Jaeel, A.J. A novel use of undesirable wiled giant reed biomass to replace aggregate in concrete. Construction and Building Materials. 2014; 67: 68-73.

33. Noori K.M.G., Ibrahim H.H. Mechanical properties of concrete using iron waste as a partial replacement of sand. Eurasian Journal of Science and Engineering. 2018; 3: 75-82. 